\title{
Quantification of LSD in illicit samples by high performance liquid chromatography
}

\author{
Pablo Alves Marinho1,*, Edna Maria Alvarez Leite² \\ ${ }^{1}$ Institute of Criminology of Minas Gerais, Belo Horizonte, ${ }^{2}$ Toxicology Laboratory, Pharmacy College, Federal University of \\ Minas Gerais
}

\begin{abstract}
In the present study, a method using high performance liquid chromatography to quantify LSD, in blotter papers seized in Minas Gerais, was optimized and validated. Linearity, precision, recovery, limits of detection and quantification, and selectivity were the parameters used to evaluate performance. The samples were extracted with methanol:water (1: 1) in an ultra-sound bath. The linearity between 0.05 and $20.00 \mu \mathrm{g} / \mathrm{mL}$ ( 0.5 and $200.0 \mu \mathrm{g}$ of LSD/blotter) was observed with satisfactory mean intra and inter assay precision $\left(\mathrm{RSD}_{\mathrm{r}}=4.4 \%\right.$ and $\mathrm{RSD}_{\mathrm{R}}=6.4 \%$, respectively $)$ and with mean recoveries of $83.4 \%$ and $84.9 \%$ to the levels of 1.00 and $20.00 \mu \mathrm{g} / \mathrm{mL}$ (10 and $200 \mu \mathrm{g} \mathrm{LSD} / \mathrm{blotter})$. The limits of detection and quantification were 0.01 and $0.05 \mu \mathrm{g} / \mathrm{mL}$, respectively ( 0.1 and $0.5 \mu \mathrm{g}$ of LSD/blotter). The samples of blotters $(\mathrm{n}=22)$ were analyzed and the mean value of $67.55 \mu \mathrm{g}$ of $\mathrm{LSD} / \mathrm{blotter}(\mathrm{RSD}=27.5 \%)$ was found. Thus, the method used showed satisfactory analytical performance, and proved suitable as an analytical tool for LSD determination in illicit samples seized by police forces.
\end{abstract}

Uniterms: LSD/detection. Forensic chemistry. Analytical toxicology. In-house validation. High Performance Liquid Chromatography/quantitative analysis.

\begin{abstract}
No presente trabalho, um método utilizando cromatografia líquida de alta eficiência foi otimizado e validado para quantificar o LSD em selos apreendidos em Minas Gerais. A linearidade, precisão, recuperação, limites de detecção e quantificação e seletividade foram os parâmetros de desempenho avaliados. As amostras foram extraídas com metanol: água (1:1) em banho de ultra-som. A linearidade entre 0,05 a $20,00 \mathrm{mg} / \mathrm{mL}(0,5$ a $200 \mu \mathrm{g}$ LSD/blotter $)$ foi observada com precisão média, intra e inter ensaio, satisfatória $\left(\mathrm{RSD}_{\mathrm{r}}=4,4 \%\right.$ e $\mathrm{RSD}_{\mathrm{R}}=6,4 \%$, respectivamente) e com recuperações médias de $83,4 \%$ e $84,9 \%$ para os níveis de LSD de 1,00 e $20,00 \mathrm{mg} / \mathrm{mL}$ ( 10 e $200 \mu \mathrm{g} \mathrm{LSD} / \mathrm{sel}$ ). Os limites de deteç̧ão e quantificação encontrados foram de 0,01 e $0,05 \mathrm{mg} / \mathrm{mL}$, respectivamente $(0,1$ e $0,5 \mu \mathrm{g} \mathrm{LSD} / \mathrm{selo})$. As amostras de selos $(\mathrm{n}=22)$ foram analisadas e o valor médio encontrado foi de $67,55 \mu \mathrm{g}$ de $\mathrm{LSD} / \mathrm{selo}$ $(\mathrm{RSD} \%=27,5)$. Desta forma, o método analítico apresentou desempenho satisfatório, capaz de ser utilizado como instrumento de análise para a determinação do LSD em amostras ilícitas apreendidas pelas forças policiais.
\end{abstract}

Unitermos: LSD/detecção. Química Forense. Toxicologia analítica. Validação intralaboratorial. Cromatografia líquida de alta efeciência/análise quantitativa.

\section{INTRODUCTION}

The Swiss chemist Albert Hofmann first synthesized LSD (lysergic acid diethylamide) in 1938. The short form LSD comes from its early code name $L S D-25$, which is an

*Correspondence: P. A. Marinho. Instituto de Criminalística de Minas Gerais. Rua Juiz de Fora, 400 - Bairro Barro Preto - 30180-060 - Belo Horizonte - MG, Brasil. E-mail: pabloalvesmarinho@yahoo.com.br abbreviation for the German "Lysergsäure-diethylamid" followed by a sequential number (NIDA, 2001; Cashman, 1980).

LSD chemical structure is shown in Figure 1.

Lysergic acid diethylamide commonly known as acid, lysergide or sweet is a semisynthetic drug made from lysergic acid, an alkaloid produced by fungus Claviceps purpurea (Oga, 2003; Schiff, 2006).

Different forms of LSD are sold on the illicit market 


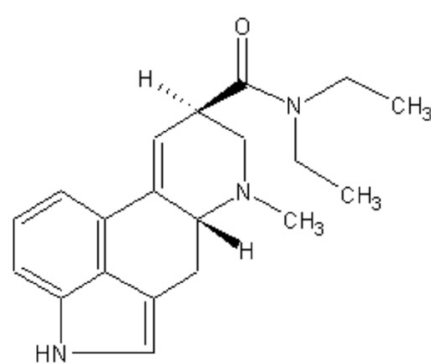

FIGURE 1 - LSD chemical structure (P.M.: 323.432; CAS: 50-37-3).

such as sugar cubes, paper dosage units (blotter papers), small tablets (microdots), and gelatin matrix containing LSD that is solidified and cut into square pieces called windowpanes (United Nations, 2003, 1989).

Research carried out in Brazil in 2005, by the Centro Brasileiro de Informações sobre Drogas Psicotrópicas- CEBRID (Brazilian Center for Information on Psychotropic Drugs) and Secretaria Nacional Antidrogas - SENAD (National Anti-drugs Secretariat) showed that $1.1 \%$ of Brazilians have used hallucinogens at least once in their lifetime. These rates are lower than those found in the survey carried out by the Substance Abuse and Mental Health Services Administration SAMHSA (14.3\%) (Carlini et al., 2005).

Brazilian law prohibits the use of LSD and its isomers in the country (Resolution 344/1998 of Agência Nacional de Vigilância Sanitária-ANVISA) but statistics compiled by the Observatório Brasileiro de Informações sobre Drogas-OBID showed an increase (539 \%) in LSD seizure by National Police from 2004 to 2006 . Thus, it is very important to identify the drugs seized.

Ultraviolet (UV) irradiation, color tests using Ehrlich's reagent, reagent of Mandelin or Marquis and thin layer chromatography (TLC) with fluorescent additive in the stationary phase for instance, can all be used to screen for LSD in illicit samples (United Nations, 1989; Moffat, 2004).

Usual techniques for quantification of LSD are high performance liquid chromatography with fluorescence, ultraviolet or mass spectrometry detection, as well as gas chromatography and capillary electrophoresis with mass spectrometry detection. (Chung et al., 2009; Shutter et al., 2009; Favretto et al., 2007).

Unfortunately, few laboratories of toxicology in Brazil and other developing countries are equipped to follow international protocols. The lack of equipment for mass spectrometry in these laboratories can be explained by the high cost of acquisition and maintenance of such equipment (GGLAS, 2008). Moreover, there are no studies on the quantitative profile of LSD in illicit samples seized in Brazil and this gap precludes intra- and inter-regional comparative studies on these samples.

Thus, the aim of the present study was to optimize and validate an analytical method for LSD determination in samples of blotter papers traded illicitly, using high performance liquid chromatography with an ultraviolet detector (HPLC-UV) and determination of the quantitative profile of the analyzed samples.

\section{MATERIAL AND METHODS}

\section{Instrument}

Chromatographic analysis was performed by a Hewlett Packard ${ }^{\circledR}$ HPLC, model HP 1200 Series, equipped with isocratic pump, ultraviolet detector and ChemStation Rev.B.02.01 software (Agilent Technologies 2001-2006). A Zorbax Eclipse XDB - C8, $5 \mu \mathrm{m}(150 \mathrm{~mm}$ x $4.6 \mathrm{~mm})$ column (Agilent Technologies ${ }^{\circledR}$ ) was used.

\section{Standards and reagents}

Lysergic acid diethylamide (LSD) - $1.0 \mathrm{mg} / \mathrm{mL}$; Lysergic acid methylpropylamide (LAMPA) $-1.0 \mathrm{mg}$ / $\mathrm{mL} ;(-) \Delta^{9}$-Tetrahydrocannabinol (THC) $-1.0 \mathrm{mg} / \mathrm{mL}$, were used, all obtained from Cerilliant Corporation ${ }^{\circledR}$ (Texas, U.S.A.). Trade standards of caffeine $\left(\right.$ Synth $\left.^{\circledR}\right)$, benzocaine (Sigma-Aldrich ${ }^{\circledR}$ ), lidocaine (Sigma- Aldri$\left.\mathrm{ch}^{\circledR}\right)$ and cocaine extract were purified by our laboratory. Acetonitrile and methanol grade HPLC (J.T. Baker ${ }^{\circledR}$ ); acid acetic $\left(\right.$ Vetec $\left.^{\circledR}\right)$ and ammonium carbonate $\left(\right.$ Reagen $\left.{ }^{\circledR}\right)$ grade PA was used.

\section{Samples}

Samples of blotters came $(\mathrm{n}=22)$ from seizures carried out by the police of Minas Gerais State between 2006 and 2009 and were sent to the Institute of Criminology of Minas Gerais in order to be examined by chemicaltoxicological assay. The blotters had an average mass of $17 \mu \mathrm{g}$ and dimensions of $7 \times 7 \mathrm{~mm}$, as shown in Figure 2.

\section{METHODS}

\section{Sample preparation}

The samples were extracted with $2.0 \mathrm{~mL}$ of methanol: water (1:1) for twenty minutes in an ultrasonic bath, changing the solvent extractor every 5 minutes, in order to extract the maximum LSD impregnated in the blotters. 


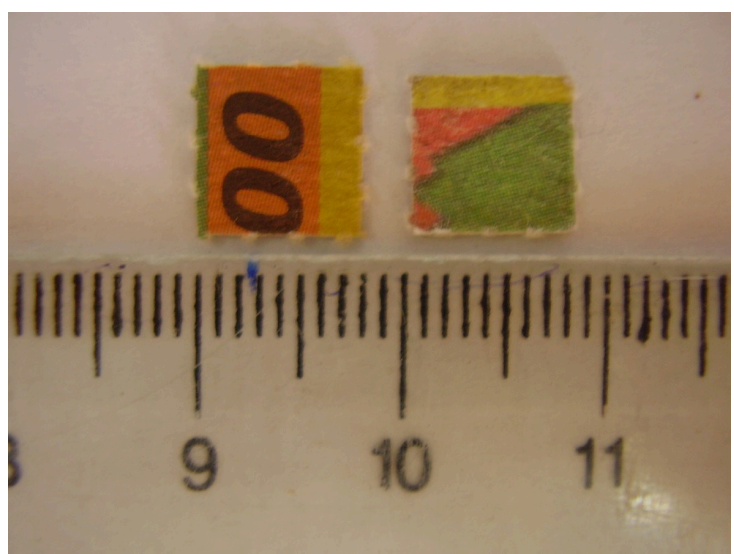

FIGURE 2 - Two samples of blotters seized and analyzed by present method.

\section{Instrumental conditions}

The mobile phase was composed of methanol:acetonitrile $(75: 25)$ - ammonium carbonate $1.0 \mathrm{~g} / \mathrm{L}(1: 1), \mathrm{pH}=8.2$. The mobile phase flow was kept in the isocratic form $(1.0 \mathrm{~mL} / \mathrm{min})$ and the injection volume was $50 \mu \mathrm{L}$. The wave length selected for LSD detection was $220 \mathrm{~nm}$ and the total running time was set at 12 minutes. The LSD retention time was $7.7 \pm 0.3$ minutes.

\section{Validation procedure}

The performance characteristics of the method were established by in-house validation procedures. During method validation the parameters linearity, precision, recovery, limits and selectivity were assessed. In order to study the method linearity, five levels of concentration of LSD were prepared in triplicate (from 0.05 to $20.0 \mu \mathrm{g} / \mathrm{mL}$ ).

The ordinary least squares method (simple linear regression) was used for the linearity curve construction, curve equation evaluation, determination coefficient $\left(\mathrm{R}^{2}\right)$ and visual inspection of graph $\mathrm{x} / \mathrm{y}$. Residues of regression were also verified.

In contrast, according to reports of numerous references, linearity cannot be evaluated by the determination of correlation coefficient alone, where a more refined statistical study is required in order to confirm linearity. The assumptions of studies of linear regression (normality, homoscedasticity, and independence) are encouraged to verify the adjustment to the proposed model (Draper, Smith, 1998; RSC, 2005; Souza, 2007; Burke, 2001).

Normality, homoscedasticity and independence were tested by the statistic tests of Ryan-Joiner (1976), Brown-Forsythe (1974) and Durbin-Watson (1951), respectively.
The Jacknife standardized residue test was used to verify the presence of outliers. This was applied successively until no outliers were detected, or until outlier presence did not exceed $22 \%$ of the initial value (Horwitz, 1995). Values outside the interval $\pm\left(\mathrm{t}_{1-\alpha / 2 ; \mathrm{n}-2}\right) \mathrm{s}_{\text {res }}$, were considered outliers $\left(\mathrm{s}_{\mathrm{res}}=\right.$ residue standard deviation).

Limit of detection (LD) and limit of quantification (LQ) were determined after successive dilutions of LSD stock solution $(20.0 \mu \mathrm{g} / \mathrm{mL})$. That concentration able to produce a signal-noise ratio of 3:1 was considered the LD. The concentration that produced a signal-noise of 10:1 and also had adequate precision $(\mathrm{CV}=8 \%)$ was established as LQ.

A precision study under repeatability conditions was conducted by injecting standard solutions of LSD diluted in methanol: water (1:1), concentrations of $0.05,10.0$ and $20.0 \mu \mathrm{g} / \mathrm{mL}$, on the same day and in quintuplicate. An intermediate precision study was conducted using these same LSD concentrations also injected in quintuplicate but on five different days.

In the present study, it was not possible to evaluate the method accuracy, as there were no certified reference materials or other reference materials available in the laboratory. Apparent recovery was therefore analyzed as an indirect accuracy parameter. Recovery was evaluated based on blotter papers, previously extracted exhaustively in order to withdraw all impregnated LSD. These blotters, considered "blanks samples", were extracted according to the item sample preparation. The extracts obtained were fortified with $1.0 \mu \mathrm{g}$ and $20.0 \mu \mathrm{g}$ of LSD in a $10 \mathrm{~mL}$ final volume and then injected into the HPLC. Responses obtained were considered $100 \%$. Other "blank blotter" papers were previously impregnated on their external surfaces with the same LSD quantity and after drying were extracted to study recovery .

In order to study selectivity, samples of some substances present in "street drugs" were extracted to verify if the retention time of these compounds coincided with that of the LSD. The examined substances were benzocaine, lidocaine, cocaine, caffeine, THC and LAMPA. Although LAMPA is not a substance used in drug abuse, it was employed in the test because many methods described in the literature use it as an internal standard.

\section{RESULTS AND DISCUSSION}

According to the tests performed, five cycles of extraction were needed in order to fully extract the LSD. In each cycle, $2 \mathrm{~mL}$ of methanol: water (1:1) mixture was used with stirring for five minutes in an ultrasonic bath. The efficiency of each cycle of LSD extraction is shown in Figure 3. 


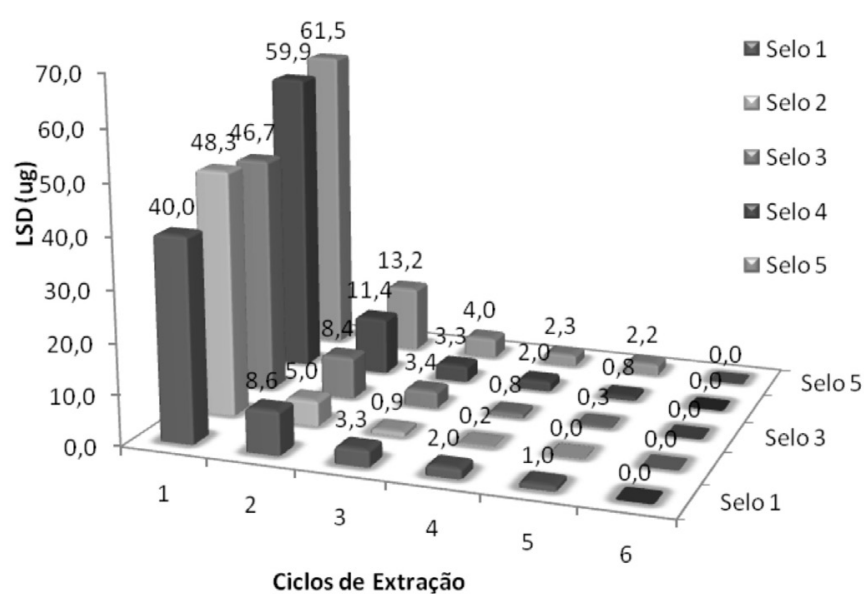

FIGURE 3 - Amount of LSD extracted from five LSD blotter papers in each cycle.

Methanol:water (1:1) was selected as the LSD solvent extractor according to the study by Veress (Veress, 1993). Blotters are usually impregnated with LSD in salt form (for example, LSD tartrate) so a high polarity solvent is more efficient to extract the drug. The results of the present study were consistent with those found by Veress 1993, as LSD levels from blotters extracted with methanol were significantly lower than those obtained using methanol:water (1:1) extraction.

Before examining the assumptions related to the linear regression, the presence of dispersed values (outliers) was analyzed by the Jacknife standardized residuals test. Only one outlier value was detected. Figure 4 shows a graph of residuals without the outlier value, which was removed earlier.

The presence of heteroscedasticity or the lack of adjustment to the linear model was not evident visually.

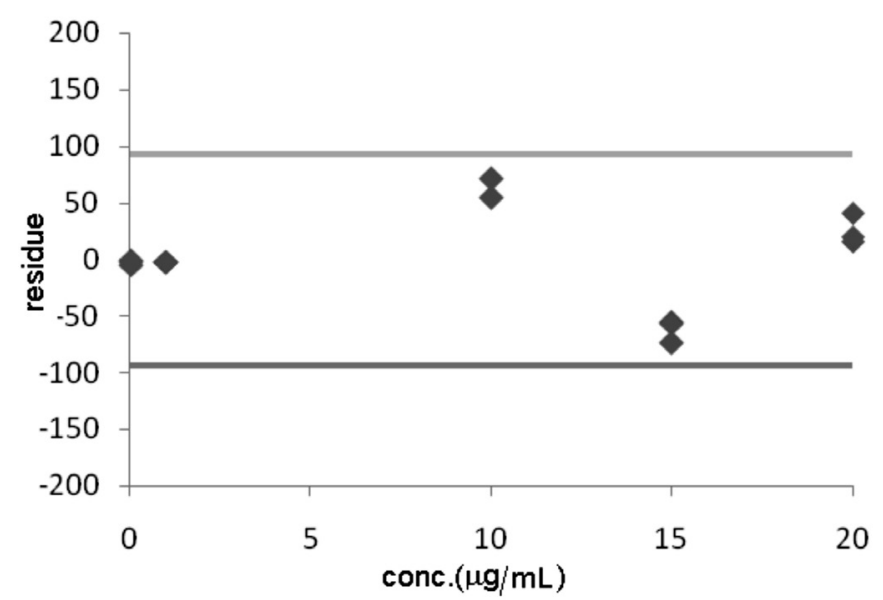

FIGURE 4 - Residual plots for outlier treatment by Jacknife standardized residuals test, demonstrating maximum and minimum allowed intervals. The horizontal lines correspond to $\pm\left(\mathrm{t}_{0.975 ; \mathrm{n}-2}\right) \mathrm{s}_{\mathrm{res}}$.
Ryan-Joiner, 1976, Brown- Forsythe, 1974 and Durbin-Watson 1951 tests were applied in order to verify the normality, homoscedasticity and independence of the regression residues, respectively (Table I.)

TABLE I - Statistical parameters for linear regression evaluation

\begin{tabular}{cc}
\hline Statistic & Value \\
\hline$N$ & 14 \\
Normality & \\
$R$ & 0.9652 \\
$P$ & $\mathrm{p}>0.10$
\end{tabular}

Homoscedasticity

$\begin{array}{cc}t L & 0.208 \\ P & 0.83\end{array}$

Independence

$\begin{array}{cc}D & 1.31 \\ P & \mathrm{p}>0.05\end{array}$

n: data number; R: Ryan-Joiner correlation coefficient; $\mathrm{t}_{\mathrm{L}}$ : Levene statistic t; p:significance; D: Durbin-Watson statistic

The linear range obtained in this study after the exclusion of outlier and linear regression assumptions evaluation was from 0.05 to $20.0 \mu \mathrm{g} / \mathrm{mL}$ ( 0.5 to $200.0 \mu \mathrm{g}$ of LSD/blotter). Figure shows the LSD linearity curve.

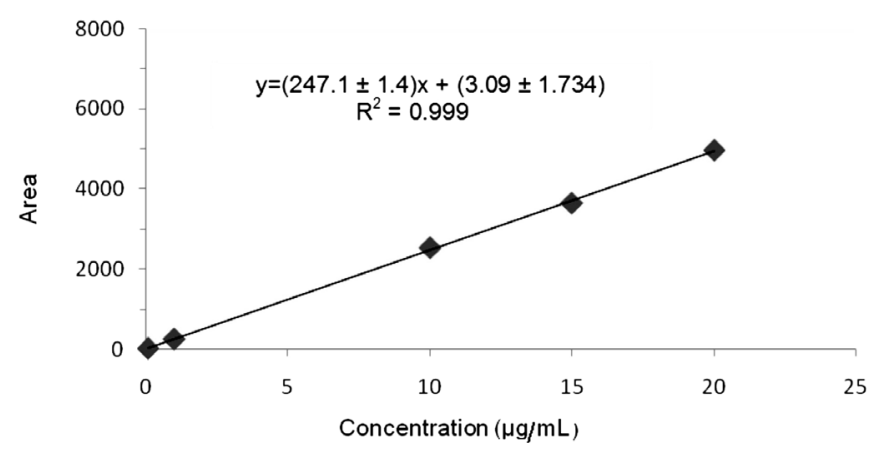

FIGURE 5 - Linear range of HPLC-UV method for LSD determination, demonstrating curve equation and determination coefficient.

LD and LQ values were 0.01 and $0.05 \mu \mathrm{g} / \mathrm{mL}$, respectively (equivalent to 0.1 and $0.5 \mu \mathrm{g}$ of $\mathrm{LSD} / \mathrm{blotter}$ ). Both of these presented adequate $\mathrm{S} / \mathrm{N}$ ratio and LQ also showed satisfactory precision (8\%). According to Thompson, 2004, the RSD under reproducibility conditions changes with the compound concentration in the sample, whereby lower concentrations show higher acceptable RSDs.

The precision under repeatability and day to day, attained in the present study are shown in Table II, and 
TABLE II - Mean and intra and inter assay relative standard deviation precision at different levels of LSD

\begin{tabular}{cccc}
\hline $\begin{array}{c}\text { Concentration } \\
(\mu \mathrm{g} / \mathrm{mL})\end{array}$ & $\begin{array}{c}\text { Amount/blotter } \\
(\mu \mathrm{g})\end{array}$ & $\begin{array}{c}\text { Precision intra assay } \\
(\mathrm{n}=5) \text { RSD }(\%)\end{array}$ & $\begin{array}{c}\text { Precision inter assay } \\
(\mathrm{n}=5) \text { RSD }(\%)\end{array}$ \\
\hline 0.05 & 0.5 & 4.75 & 8.74 \\
10.0 & 100 & 4.51 & 6.04 \\
20.0 & 200 & 3.84 & 4.50 \\
\hline
\end{tabular}

TABLE III - Mean recovery at two different levels of concentration and respective relative standard deviation

\begin{tabular}{cccc}
\hline Concentration $(\mu \mathrm{g} / \mathrm{mL})$ & Amount $/$ blotter $(\mu \mathrm{g})$ & Mean Recovery & RSD $(\%)$ \\
\hline 1.0 & 10 & 83.84 & 2.72 \\
20.0 & 200 & 84.85 & 7.49 \\
\hline
\end{tabular}

the results are in agreement with Pocklington, 1990 (11\% and $23 \%$ ).

Percentage recovery found for the two different concentrations studied can be seen in Table III. These data are in accordance with those reported by the European Commission, 2002, that cites acceptable recovery values as lying in the range between 80 to $110 \%$ for substances at concentrations higher than $0.01 \mathrm{ppm}$ in the sample.

No substance used to verify the method selectivity showed a retention time able to interfere with the LSD chromatographic peak (Figures 6,7 and 8).

Twenty-two (22) blotter samples were analyzed and quantified by the method validated. For LSD quantification, a calibration curve was prepared with three levels of concentration, in triplicate, using "blank blotters" as explained in the recovery study described above. The results are shown in Table IV. Figure 9 shows a chromatogram of an analyzed LSD blotter sample.

Other "blank blotter" papers were previously impregnated on their external surface with the same LSD quantity and then dried and submitted to the extraction method for recovery calculation.

The amount of LSD determined in the analyzed samples was consistent with the values found in literature, lying within the range described by the literature which reports a wide variation of LSD in blotters (30 to $500 \mu \mathrm{g}$ ) analyzed by different authors (Veress, 1993; United Nations, 1989; Clarkson et al., 1998).

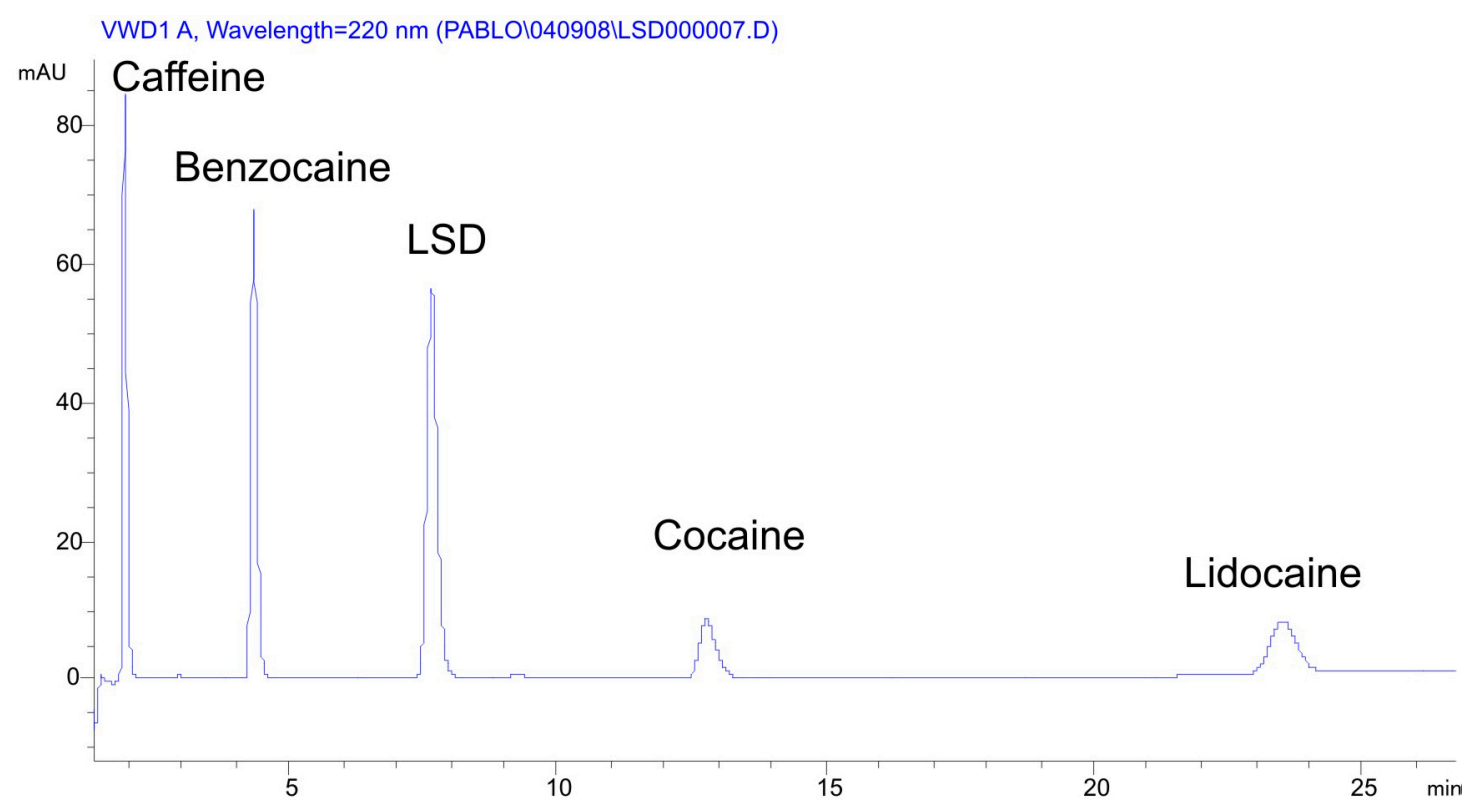

FIGURE 6 - Chromatogram obtained after injection of standards of caffeine $\left(t_{r}=1.92 \mathrm{~min}\right)$, benzocaine $\left(\mathrm{t}_{\mathrm{r}}=4.33 \mathrm{~min}\right)$, LSD $\left(\mathrm{t}_{\mathrm{r}}=\right.$ $7.64 \mathrm{~min})$, cocaine $\left(\mathrm{t}_{\mathrm{r}}=12.77 \mathrm{~min}\right)$ and lidocaine $\left(\mathrm{t}_{\mathrm{r}}=23.51 \mathrm{~min}\right)$. 


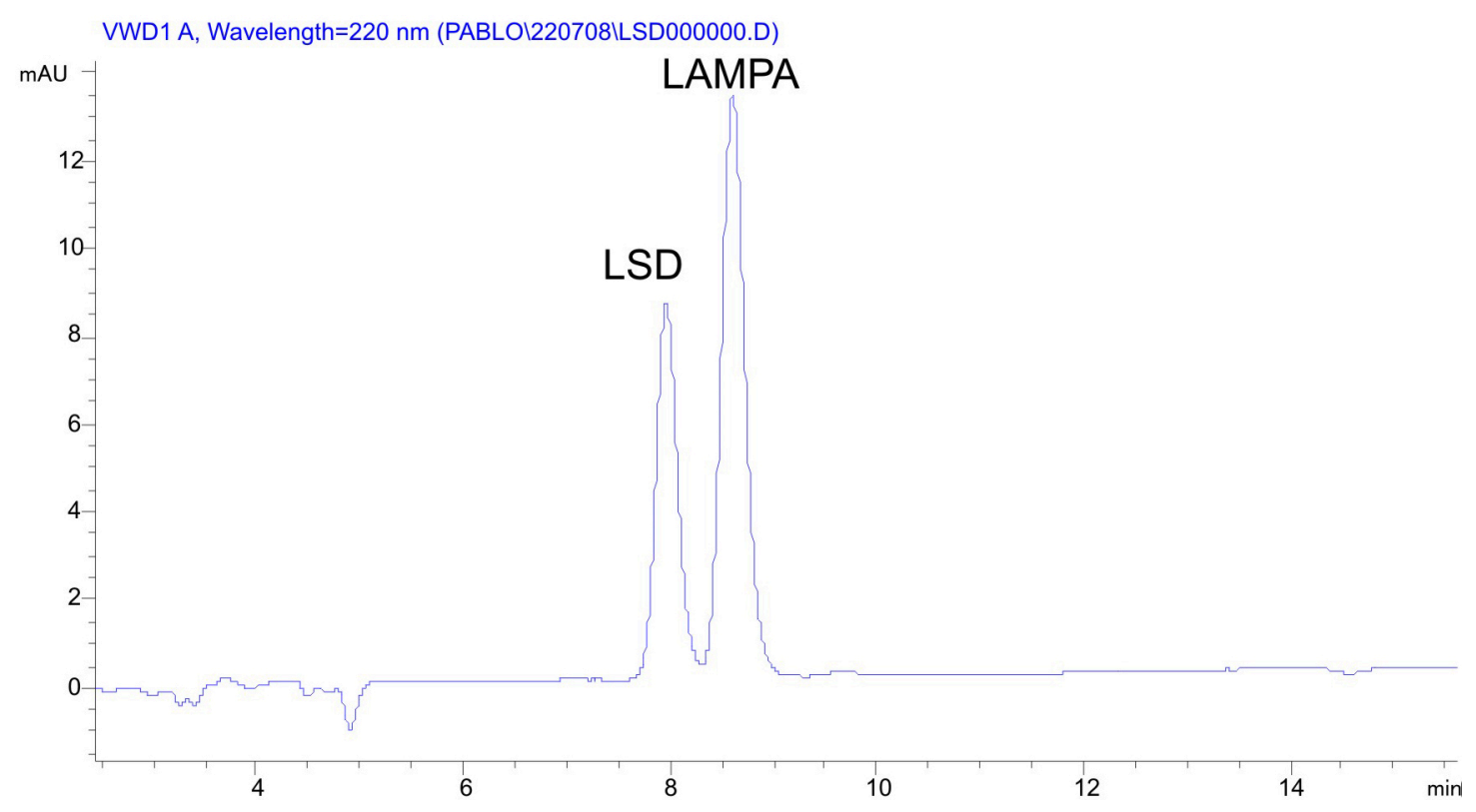

FIGURE 7 - Chromatogram obtained after injection of standards of LSD $\left(t_{r}=7.96 \mathrm{~min}\right)$ and LAMPA $\left(t_{r}=8.60 \mathrm{~min}\right)$.

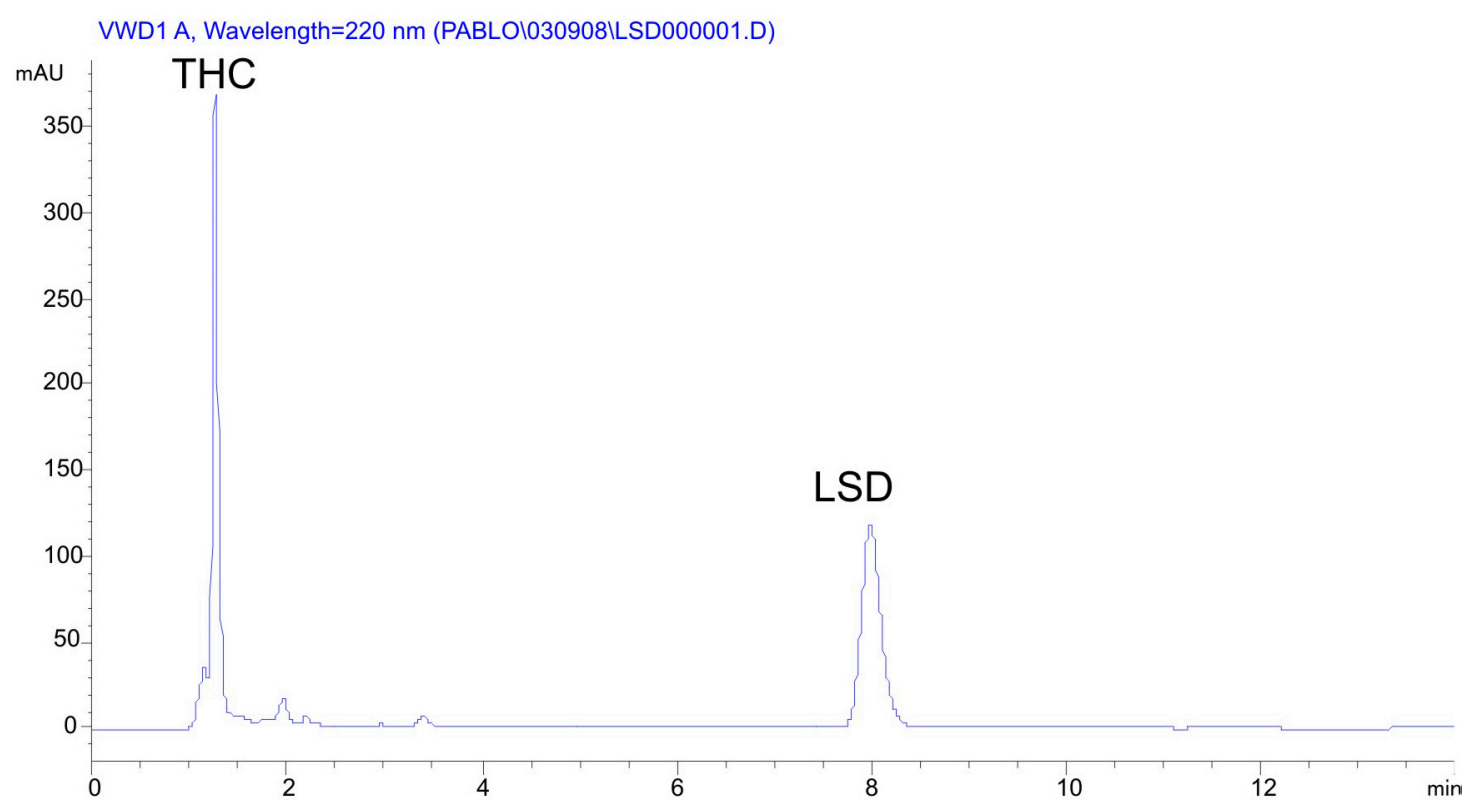

FIGURE 8 - Chromatogram obtained after injection of standards of THC $\left(t_{r}=1.25 \mathrm{~min}\right)$ and LSD $\left(\mathrm{t}_{\mathrm{r}}=7.98 \mathrm{~min}\right)$.

In order to ascertain the degree of LSD homogeneity of different blotters, samples from the same pack were analyzed and then compared with samples from other seizures. A lower variation was found in the blotter derived from the same pack of $\operatorname{LSD}(\mathrm{n}=5, \mathrm{RSD}=3.9 \%)$, compared to the variation found in different seizure blotters $(n=11$, $\mathrm{RSD}=31.5 \%$ ). This result was expected since the blotters seized in different places may have come from different sources, thus the LSD solution concentration employed to impregnate the blotters, as well as the impregnation process may vary among the dealers.

\section{CONCLUSION}

It is known that advanced analytical equipment is not always available in forensic laboratories in developing countries. Thus, it is essential to develop, optimize or adapt analytical methods that are economically accessible, yet maintain their analytical reliability which is indispensable in forensic toxicological assays. The method proposed in the present study proved fit for its purpose. It is important to emphasize that, according to the literature, this is the first Brazilian study to have determined the amount of 


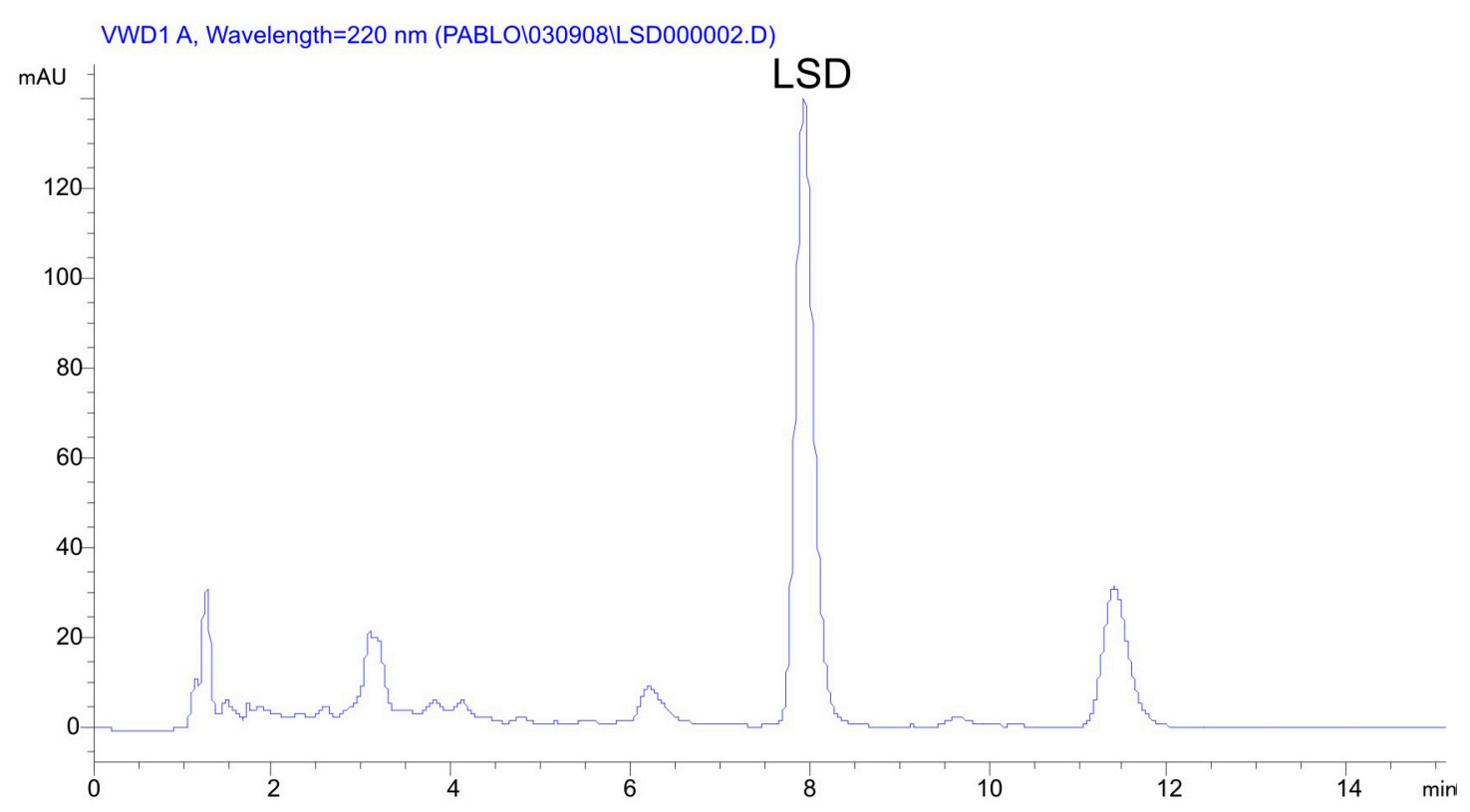

FIGURE 9 - Chromatogram after injection of blotter extract in methanol: water (1:1) tr LSD = $7.86 \mathrm{~min}$.

TABLE IV - LSD in 22 blotters seized by Police of Minas Gerais state

\begin{tabular}{cc}
\hline LSD $(\mu \mathrm{g})$ & Blotters \\
\hline 31.51 & 17 \\
33.91 & 19 \\
51.02 & 18 \\
53.36 & 2 \\
53.72 & 4 \\
54.43 & 1 \\
55.08 & 3 \\
55.34 & 21 \\
57.58 & 20 \\
58.72 & 5 \\
62.79 & 15 \\
65.07 & 22 \\
76.25 & 16 \\
78.11 & 8 \\
81.69 & 12 \\
81.98 & 6 \\
85.10 & 11 \\
86.82 & 10 \\
87.63 & 7 \\
88.58 & 9 \\
92.88 & 13 \\
94.60 & 14 \\
\hline
\end{tabular}

Mean value: $67.55 \pm 18.61(\mathrm{CV}=27.5 \%)$
LSD in illicit samples. Further similar studies carried out in the future with samples seized in other states, will allow a quantitative profile of the drug in these samples to be defined at the national level.

\section{REFERENCES}

BRASIL. ANVISA. Resolução da diretoria colegiada - RDC $\mathrm{n}^{\mathrm{o}} 07$, de 26 de fevereiro de 2009. Available at: http://elegis.anvisa.gov.br/leisref/public/ showAct.php?id=35907. Access on: 20 mar. 2009.

BROWN, M.B.; FORSYTHE, A.B. Robust tests for the equality of variances. J. Am. Stat. Assoc., v.69, n.346, p.364-367, 1974.

BURKE, S. Regression and calibration. $L C \cdot G C$ Europe Statistics and Data Analysis Online Supplement. p.13-18, 2001. Available at: https://www.webdepot.umontreal. ca/ Usagers/sauves/MonDepotPublic/CHM\%203103/ LCGC\%20Eur\%20Burke\%202001\%20-\%202\%20 de\%204.pdf. Access on: 03 jun. 2008

CARLINI, E.A.; GALDURÓZ, J.C.F.; NOTO, A.R.; FONSECA, A.; MARTINS; CARLINI, C.M.; OLIVEIRA, L.G; NAPPO, S.A.; MOURA, Y.G; SANCHEZ, Z.V.D.M - II Levantamento Domiciliar sobre o uso de drogas psicotrópicas no Brasil: estudo envolvendo as 108 maiores cidades do País - 2005. São Paulo: CEBRID, 2006. 440 p. 
CASHMAN, J. LSD. São Paulo: Perspectiva, 1970. 155 p.

CHUNG, A.; HUDSON, J.; MCKAY, G. Validated ultraperformance liquid chromatography-tandem mass spectrometry method for analyzing LSD, iso-LSD, norLSD, and O-H-LSD in blood and urine. J. Anal. Toxicol. v.33, n.5, p.253-259, 2009.

DRAPER, N.; SMITH, H. Applied regression analysis. New York: Wiley, 1998. $706 \mathrm{p}$.

DURBIN, J.; WATSON, G.S. Testing for serial correlation in least squares regression II. Biometrika, v.38, n.1-2, p.159178, 1951.

EUROPEAN COMMISSION (EC). Commission decision 2002/657/EC of 12 August 2002. Implementing Council Directive 96/23/EC concerning performance of analytical methods and the interpretation of results. Off. J. Eur. Commun., v.45, n.221, p.8-36,2002.

FAVRETTO, D.; FRISON, G.; MAIETTI S.; FERRARA, S.D. LC-ESI-MS/MS on an ion trap for the determination of LSD, iso -LSD, nor -LSD and 2-oxo-3-hydroxy-LSD in blood, urine and vitreous humor. Int. J. Legal Med., v.121, n.4, p.259-265, 2007.

GERÊNCIA GERAL DE LABORATÓRIOS DE SAÚDE PÚBLICA-GGLAS. Levantamento de laboratórios analíticos de Toxicologia Forense. ANVISA - REBLAS. 2004, 256p. Available at: http://www.anvisa.gov.br/reblas/ pesquisa.htm. Access on: 23 apr. 2008.

HORWITZ, W. Protocol for the design, conduct and interpretation of method-performance studies. Pure Appl. Chem., v.67, n.2, p.331-343, 1995.

MOFFAT, A.C.; OSSELTON M.D.; WIDDOP, B. Clarke's analysis of drugs and poisons. 3.ed. London: The Pharmaceutical Press, 2004. 2101 p.

NICHOLS, D.E. Hallucinogens. Pharmacol. Ther., v.101, n.2, p.131-181, 2004.

\section{OBSERVATÓRIO BRASILEIRO DE INFORMAÇÕES} SOBRE DROGAS (OBID). Apreensão de drogas. Available at: http://www.obid.senad.gov.br/portais / OBID/biblioteca/documentos/Dados_Estatisticos/ indicadores/327433.pdf. Accessed on: $14^{\text {th }}$ June 2009.
POCKLINGTON, W.E. Harmonized Protocols for the Adoption of Standardized Analytical Methods and for the Presentation of their Performance Characteristics. Pure Appl. Chem., v.62, n.1, p.149-162, 1990.

POSTIGO, C.; ALDA, M.J.L.; VIANA M.; QUEROL, X.; ALASTUEY, A.; ARTINANO, B.; BARCELO, D. Determination of drugs of abuse in airborne particles by pressurized liquid extraction and liquid chromatographyelectrospray-tandem mass spectrometry. Anal. Chem., v.81, n.11, p.4382-4388, 2009.

ROCHA, O.G.F. Estudo da intoxicação por estrôncio em pacientes portadores de insuficiência renal crônica, submetidos a tratamento dialítico. Belo Horizonte, 2003. 106 f. [Tese Doutorado em Ciências Farmacêuticas. Faculdade de Farmácia. Universidade Federal de Minas Gerais].

ROYAL SOCIETY OF CHEMISTRY (RSC). Analytical Methods Committee - Technical Brief : Is my calibration linear? RSC, 2005. Available at: http://www.rsc.org/pdf/ amc/brief3.pdf. Accessed on: 20.oct.2009

RYAN, T.A.; JOINER, B.L. Normal probability plots and tests for normality. The State College: Pennsylvania State University, 1976. Available at: <http://www.minitab.com/ uploadedFiles/Shared_Resources/Documents/Articles/ normalprobability_plots.pdf $>$. Accessed on: $14^{\text {th }}$ jun. 2009.

SOUZA, S.V.C. Procedimento para validação intralaboratorial de métodos de ensaio: delineamento e aplicabilidade em análises de alimento. Belo Horizonte, 2007. 297 f. [Tese de Doutorado em Ciências de Alimentos. Faculdade de Farmácia. Universidade Federal de Minas Gerais].

THOMPSON, M.; ELLISON, S.L.R.;WOOD, R. Harmonized guidelines for single-laboratory validation of methods of analysis. Pure Appl. Chem., v.74, n.5, p.835-855, 2002.

THOMPSON, M. The amazing Horwitz function. AMC Technical Brief, n.17, 2004. Available at: <http://www.rsc. org/images/brief17_tcm18-25961.pdf.> Accessed on: 20. Oct. 2009

UNITED NATIONS. Office on drugs and crime. Terminology and information on drugs. 2.ed. New York, 2003. 72 p. 
UNITED NATIONS. Recommended method for testing lysergide (LSD). Manual for use by National Narcotic Laboratories, Division of Narcotic Drugs. Vienna, 1989. 21p.

VERESS, T. Study of the extraction of LSD from illicit blotters for HPLC determination. J. Forensic Sci., v.38, n.5, p.11051110, 1993.
VESSMAN, J.; RALUCA I. S.; VAN STANDEN J. F.; DANZER, K.; LINDNER W.; BUNS, D.T.; FAJGELJ, A.; MÜLLER, H. Selectivity in analytical chemistry. Pure Appl. Chem., v.73, n.8, p.1381-1386, 2001.

Received for publication on $23^{\text {th }}$ July 2009. Accepted for publication on $13^{\text {th }}$ May 2010. 